Журнал«Герспективитаінновації науки

(Серія«Гедагогіка», Серія«ГТихологія», Серія «Медицина»

№5(5) 2021

УДК 378. 013+370.711

https://doi.org/10.52058/2786-4952 -2021-5(5)-58-68

Алєкссєва Світлана Володимирівна доктор педагогічних наук, старший науковий співробітник, головний науковий співробітник відділу дидактики Інституту педагогіки, Національна академія педагогічних наук України, вул. Січових Стрільців, 52-д, м. Київ, 04053, тел.: (044) 481-37-71, e-mail: sv-05@ukr.net, https://orcid.org/0000-0002-8132-0465

\title{
ТЕХНОЛОГІЯ ФОРМУВАННЯ ІНДИВІДУАЛЬНОЇ ОСВІТНЬОЇ ТРАЕКТОРІЇ УЧНІВ ПРОФІЛЬНОЇ ШКОЛИ
}

Анотація. Профільна школа є одним із ключових напрямів модернізації та удосконалення системи освіти, що передбачає індивідуалізацію навчання здобувачів освіти відповідно до їх освітніх потреб, нахилів, здібностей, орієнтації на професійний вибір, на майбутню професію. Концепція Нової української школи декларує засади особистісно-орієнтованої моделі освіти, у рамках якої профільна школа орієнтована на розвиток здібностей старшокласників, максимально враховує їх потреби та інтереси, на практиці реалізує можливість свідомого кар'єрного самовизначення підлітків, їхн соціалізацію.

Поняття індивідуальної освітньої траєкторії пов’язують 3 дидактичним комплексом, що забезпечує оптимальні можливості для розвитку і творчого потенціалу учнів. Технологія формування індивідуальної освітньої траєкторії учнів профільної школи $€$ комплексною, інтегративною, науково обгрунтованою системою, що складається зі функційно-структурних компонентів: концептуального (визначає мету, методологічне підгрунтя та принципи); змістового (становить систему знань для успішної самореалізації у суспільстві, професійного самовизначення, формування їх світогляду, набуття соціального досвіду, підготовку до суспільного життя i професійної діяльності); процесуально-координуючого (характеризує етапи реалізації, методи, форми, засоби навчання), контрольно-регулюючого (спрямований на результативність та ефективність функціонування, внесення оптимальних корективів в освітній процес). Технологічність формування індивідуальної освітньої траєкторії забезпечити особистісно-орієнтовану модель навчання старшокласників, що сприяє всебічному розвитку здібностей учнів профільної школи, створює умови для їхньої професійної орієнтації. Формування індивідуальної освітньої траєкторії це процес багатокомпонентним і включає: загальноосвітню підготовку учнів; профільну підготовку; професійну орієнтацію (логічно узгоджену програму, орієнтовану на професійне самовизначення); варіативний курс 3 професійної кар'єри (орієнтований на формування загальних та спеціальних практичних умінь і навичок необхідних 
для побудови професійної кар'єри, розширення світогляду, ціннісного ставлення до майбутньої професійної реалізації).

Ключові слова: технологія, індивідуальна освітня траєкторія, профільна школа, професійна орієнтація, професійна кар'єра.

Alieksieieva Svitlana Volodymyrivna Doctor of Pedagogical Sciences, senior researcher, chief researcher of the Department of didactics of the Institute of Pedagogy of the National Academy of Educational Sciences of Ukraine, Sichevykh Streltsov St., 52-d, Kyiv, 04053, tel.: (044) 481-37-71, e-mail: sv-05@ukr.net, https://orcid.org/0000-0002-8132-0465

\section{TECHNOLOGY OF FORMING AN INDIVIDUAL EDUCATIONAL TRAJECTORY OF THE PROFESSION-ORIENTED SCHOOL STUDENTS'}

Abstract. Profession-oriented school is one of the key areas of modernization and improvement of the education system, which provides individualization of training of education applicants in accordance with their educational needs, inclinations, abilities, orientation to professional choice to the future profession. The concept of the New Ukrainian school declares the basics of a personality-oriented model of education, in which the profession-oriented school is focused on the development of the high school students' abilities, takes into account their needs and interests as much as possible, and implements in practice the possibility of conscious career self-determination of teenagers, their socialization.

The concept of an individual educational trajectory is associated with a didactic complex that provides optimal opportunities for the students' development and creative potential. The technology of forming the students' individual educational trajectory of a specialized school is a complex, integrative, scientifically based system consisting of functional and structural components: conceptual (defines the goal, methodological basis and principles); content (makes up a system of knowledge for successful self-realization in society, professional self-determination, formation of their worldview, acquisition of social experience, preparation for public life and professional activities); process-coordinating (characterizes the stages of implementation, methods, forms, means of training), control-regulating (aimed at the effectiveness and efficiency of functioning, making optimal adjustments to the educational process). Technologically advanced formation of an individual educational trajectory to provide a personality-oriented model of the high school students' teaching, which contributes to the comprehensive development of the profession-oriented school students' abilities, creates conditions for their professional orientation. The formation of an individual educational trajectory is a multicomponent process and includes: students' general education training; profession-oriented training; professional orientation (a logically coordinated program focused on professional self-determination); variable course on professional career (focused on the formation of general and special practical skills 
and abilities necessary for building a professional career, expanding the worldview, value attitude to future professional implementation).

Keywords: technology, individual educational trajectory, profession-oriented school, professional orientation, professional career.

Постановка проблеми. Профільна школа є одним із ключових напрямів модернізації та удосконалення системи освіти, що передбачає оновлення, індивідуалізацію та диференціацію навчання здобувачів освіти відповідно до їх освітніх потреб, нахилів, здібностей, орієнтації на професійний вибір, на майбутню професію. Концепція Нової української школи декларує засади особистісно-орієнтованої моделі освіти, у рамках якої профільна школа орієнтована на розвиток здібностей старшокласників, максимально враховує їх потреби та інтереси, на практиці реалізує можливість свідомого кар'єрного самовизначення підлітків, їхню соціалізацію, незалежно від місця проживання та стану здоров'я.

В Законі України «Про освіту» (2017) [1] визначено, що основні завдання сучасної освіти полягають у забезпеченні всебічного розвитку особистості як найвищої цінності суспільства, її талантів, інтелектуальних, творчих, фізичних здібностей, формування компетентностей і цінностей, необхідних для успішної самореалізації. Розв'язання поставлених завдань можливо завдяки впровадженню індивідуальної освітньої траєкторії, що орієнтована на розвиток індивідуально-особистісного потенціалу учня. Слід також зазначити, що у першій статті цього Закону індивідуальна освітня траєкторія визначається як персональний шлях реалізації особистісного потенціалу здобувачів освіти, що формується 3 урахуванням їхніх здібностей, інтересів, потреб, мотивації, можливостей та досвіду. За такого підходу, стає можливим вибір освітніх компонентів за бажаним профілем, а також відбір видів й форм навчання, що закладаються в індивідуальну освітню траєкторію.

Отже, можна вважати, що індивідуальна освітня траєкторія автентична профілю навчання, що забезпечує організацію диференційованої підготовки, яка передбачає поглиблене i професійно зорієнтоване вивчення циклу споріднених предметів суспільно-гуманітарного, філологічного, художньоестетичного, природничо-математичного, технологічного, спортивного напряму. Індивідуальна освітня траєкторія в закладі освіти може бути реалізована через індивідуальний навчальний план або індивідуальну програму розвитку (для учнів 3 особливими освітніми потребами). Індивідуальний навчальний план - це документ, що визначає послідовність освітніх компонентів, форм і темпу засвоєння освітньої програми, який розробляється закладом освіти у взаємодії із здобувачем освіти за необхідними та наявними для цього ресурсами.

Для формування індивідуальної освітньої траєкторії учнів профільної школи необхідно створення педагогічної технології, яка приводить старшокласників до усвідомлення освітніх маршрутів, що сформовані під їхні 
індивідуальні потреби, з урахуванням особистих цілей, захоплень, досягнень, успішності, майбутніх кар'єрних інтересів.

Аналіз останніх досліджень і публікацій. Поняття індивідуальної освітньої траєкторії пов'язують 3 дидактичним комплексом, що забезпечує оптимальні можливості для розвитку і творчого потенціалу учнів. Важливі аспекти іiі формування висвітлюються ученими А. Хуторським, Н. Суртаєвою, I. Каньковським, Т. Коростіянець, Я. Сухенко, М. Гринько, Т. Ковальовою. Однак, впровадження особистісно-орієнтованої організації навчальної діяльності, яка передбачає побудову освітнього процесу в контексті реалізації індивідуальних устремлінь, вироблення життєвих стратегій тільки починаються, тому питання технології формування індивідуальної освітньої траєкторії учнів профільної школи поки що не систематизовані і розроблені не в повному обсязі.

Мета статті - обгрунтування основних структурних компонентів технології формування індивідуальної освітньої траєкторії учнів профільної школи

Виклад основного матеріалу. Технологія формування індивідуальної освітньої траєкторії учнів профільної школи є комплексною, інтегративною, науково обгрунтованою системою, що складається зі функційно-структурних компонентів: концептуального (визначає мету, методологічне підгрунтя та принципи); змістового (становить систему знань для успішної самореалізації у суспільстві, професійного самовизначення, формування їх світогляду, набуття соціального досвіду, підготовку до суспільного життя i професійної діяльності); процесуально-координуючого (характеризує етапи реалізації, методи, форми, засоби навчання), контрольно-регулюючого (спрямований на результативність та ефективність функціонування, внесення оптимальних корективів в освітній процес). Технологічність формування індивідуальної освітньої траєкторії забезпечити особистісно-орієнтовану модель навчання старшокласників, що сприяє всебічному розвитку здібностей учнів профільної школи, створює умови для їхньої професійної орієнтації.

Провідна ідея технології формування індивідуальної освітньої траєкторії учнів профільної школи, що грунтується на концептуальних засадах наукових положень педагогіки, психології, теорії творчості, закономірностях профільного навчання і принципів освітнього процесу, полягає у забезпеченні персонального шляху реалізації особистісного потенціалу старшокласників, який формується з урахуванням їхніх здібностей, інтересів, потреб, мотивації, можливостей та досвіду. Сучасний випускник має володіти компетентностями та наскрізними уміннями успішної професійної самореалізації, усвідомленими кар’єрними орієнтаціями, готовності до побудови професійної кар'єри.

Концептуальний компонент технології. Мета технології формування індивідуальної освітньої траєкторії полягає у цілеспрямованій загальноосвітній та кар'єро-орієнтованій підготовці старшокласників в профільній школі, у відповідності до їхніх індивідуальних нахилів, можливостей, здібностей, 
Журнал«Герспективитаінновації наукиљ

(Серія «Гедагогіка», Серія «Гиихологія»), Серія«Медицина»

№5(5) 2021

потреб, на засадах міждисциплінарності, інтегративності, практичної спрямованості, що сприятиме успішному професійному самовизначенню учнів.

Цілі технології формування індивідуальної освітньої траєкторії учнів профільної школи конкретизуються :

забезпеченням професійній орієнтації, самоактуалізації, свідомому кар'єрному самовизначенню старшокласників, їх соціалізацією незалежно від місця проживання, стану здоров’я.

- формуванням системи ціннісних та усвідомлених кар'єрних орієнтацій випускників профільної школи, всебічним розвитком учня як цілісної особистості, його обдарувань, духовності й культури, формуванням громадянина України, здатного до свідомого суспільного вибору;

- розвитком в учнів профільної школи компетентностей та універсальних навичок (soft skills) для успішної самореалізації в суспільстві.

Індивідуальна освітня траєкторії $\epsilon$ концептуальним орієнтиром формування таких компетентностей як підприємливість та фінансова грамотність(передбачає ініціативність, готовність брати відповідальність за власні рішення, вміння організовувати діяльність для досягнення цілей); інноваційність (відкритості до нових ідей, ініціювання змін у класі, школі, громаді); здатність до навчання впродовж життя; громадянська та соціальна компетентність (пов'язані з активністю у житті класу і школи, вміння діяти в конфліктних ситуаціях, ідеями усвідомлення рівних прав і можливостей).

Концептуальним підгрунтям технології формування індивідуальної освітньої траєкторії учнів профільної школи $\epsilon$ взаємозв'язок i взаємозумовленість загальнонаукової та конкретно-наукової методології 3 відповідними науковими підходами.

Методологічний концепт технології формування індивідуальної освітньої траєкторії учнів профільної школи визначається сукупністю взаємопов'язаних та взаємодоповнюючих підходів: аксіологічного (що забезпечує гуманістичну спрямованість навчання учнів профільної школи, формування у них загальнолюдських і професійних цінностей, зокрема, ціннісного ставлення до професійної кар'єри); синергетичного (характеризує освітні компоненти підготовки молоді, вектори іiі професійного самовизначення та складні, відкриті, нелінійні, системні зв’язки такої підготовки з сучасними тенденціями розвитку ринку праці); компетентнісного (передбачає спрямованість на формування в учнів компетентностей, м'яких універсальних міжпрофесійних навичок для успішної професійної кар'єри, самореалізації в суспільстві); особистісно орієнтованого (сприяє становленню цілісної особистості учня 3 усвідомленими кар'єрними орієнтаціями, самобутністю, індивідуальністю); діяльнісного (дає змогу стимулювати пізнавальну діяльність старшокласників, їхню активність, творчу ініціативність, спонукати до самоорганізації, успішної майбутньої кар'єри), комплексного (забезпечує єдність методологічних підходів, реалізацію технології формування індивідуальної освітньої траєкторії учнів профільної школи). 
Теоретичні засади технології формування індивідуальної освітньої траєкторії учнів профільної школи грунтуються на методології цілісного педагогічного процесу, ідеях і педагогічних принципах: загальнодидактичних (індивідуалізації, цілеспрямованості педагогічного процесу, системності, гуманізації, варіативності, гнучкості, діагностико-прогностичної реалізованості, інтегративності, доступності, компетентності, індивідуальноособистісної спрямованості, поваги до особистості) та специфічних (персоналізації, адаптивності, насиченості освітнього середовища, полімодальності (мультимедийности), навчанні у співпраці i взаємодії, успішності в навчанні, включеного оцінювання, доцільності, практикоорієнтованості, соціальності). Педагогічні принципи реалізують умови для добровільного вибору учнями профілю навчання, виходячи 3 власних пізнавальних інтересів, здібностей, досягнутих результатів навчання й професійних намірів, широкого вибору змісту освітніх програм та можливостей iї корекції, перехід від передачі знань до навчання 3 набуттям досвіду, розвитку творчого потенціалу особистості, підтримки інтересів учнів, моніторингу їхніх персональних показників розвитку та освітніх результатів, насичення освітнього простору інформаційними ресурсам, інноваційними за своєю суттю, активної багатосторонньої комунікації (контактної й мережевої), створення позитивної емоційної атмосфери, ситуацій успіху, які орієнтують на саморозвиток, самовдосконалення.

Змістовий компонент технології формування індивідуальної освітньої траєкторії учнів профільної школи визначає професійно-розвивальний складник освітньої програми і реалізує надання профорієнтаційних послуг. Цей компонент технології грунтується на конгломераті загальноосвітньої й профільної підготовки з активною професійною орієнтацією та формування готовності до професійної кар'єри.

Через змістовий компонент технології формування індивідуальної освітньої траєкторії учнів профільної школи розкривається когнітивна складова системи навчання старшокласників. Зокрема, складниками змістового компоненту формування індивідуальної освітньої траєкторії учнів профільної школи $є$ когнітивний (знання), процесуальний (уміння, навички), особистісний (особистісні якості, ціннісні орієнтації, емоційні стани). Когнітивний компонент, елемент «знання», інтерпретується як інформаційний матеріал, яким оволодівають старшокласники, та на основі яких згодом формуються уміння і навички. Інформаційний матеріал компонується за напрямами, що охоплюють оптимальне пізнання всебічного вивчення професій. Процесуальний компонент характеризується формуванням базових умінь та навичок (загальні, інтелектуальні, комунікативні, спеціальні. Особистісний компонент пов'язаний 3 цілеспрямованим формуванням системи значущих ціннісних орієнтацій, розвитком емоційно-почуттєвої сфери. Цей компонент визначається ціннісними орієнтаціями діяльності й поведінки особистості, емоційними станами та ціннісними установками, які необхідно актуалізувати в 
освітньому процесі (комунікативні, мотиваційні, естетичні, особисті та пізнавальні інтереси), особистісними якостями (особистісне та професійне самовизначення, орієнтація в соціальних ролях та міжособистісних стосунках).

За змістом технологія формування індивідуальної освітньої траєкторії $\epsilon$ цілеспрямованим процесом, що орієнтований на розвиток мотиваційноціннісної, інтелектуально-пізнавальної, соціально-практичної сфери учнів профільної школи. Цей процес $є$ багатокомпонентним та включає: загальноосвітню підготовку учнів (навчання за Державним стандартом); профільну підготовку (реалізує цілі, завдання і зміст навчання за конкретним профілем, що передбачає розширене, поглиблене, професійно зорієнтоване вивчення споріднених предметів, які забезпечують прикладне спрямування інтеграції знань, методів пізнання та їх застосування); професійну орієнтацію (логічно узгоджену програму, орієнтовану на професійне самовизначення); варіативний курс 3 професійної кар'єри (орієнтований на формування загальних та спеціальних практичних умінь і навичок необхідних для побудови професійної кар'єри, розширення світогляду, ціннісного ставлення до майбутньої професійної реалізації). Формування індивідуальної освітньої траєкторії учнів профільної школи передбачає вивчення ринку праці, детальне знайомлення зі світом професій, спеціальностями, галузевими та кар'єрними кластерами за профільними напрямками, що дасть змогу старшокласникам зрозуміти зв'язок між навчальними предметами та професіями.

Інтеграція загальноосвітньої та профільної підготовки 3 активною професійною орієнтацією забезпечить відбір та об'єднання навчального матеріалу з різних предметів для цілісного і різнобічного розв'язання важливої наскрізної проблеми всебічного розвитку особистості як найвищої цінності суспільства, ¥ї талантів, інтелектуальних, творчих, фізичних здібностей, формування компетентностей $\mathrm{i}$ цінностей, необхідних для успішної самореалізації. Слід зазначити, що Державний стандарт базової середньої освіти [3] містить перелік компетентностей та наскрізних умінь учнів, розвиток яких не буде цілісним без належної професійної орієнтації. Зокрема, це здатність реагувати на зміни, відкритість до нових ідей, вміння ставити перед собою цілі, знаходити можливості для навчання й саморозвитку, підприємливість тощо. Ми погоджуємося 3 думкою О. Дубасенюк, що змістовий компонент передбачає включення таких складників як аксіологічний (орієнтація на загальнолюдські, особистісні, професійні цінності), когнітивний (базові, профільні, профорієнтаційні знання), діяльнісно-творчий (стійкий пізнавальний інтерес, впевненість у своїх можливостях, прагнення до самовираження, самореалізації, особистісному саморозвитку, прагнення до творчих досягнень), які відповідають компонентам творчої особистості [2].

Профільне навчання передбачає поглиблене, професійно зорієнтоване вивчення циклу споріднених предметів за освітніми галузями (мовнолітературною; математичною; природничою; технологічною; інформативною; 
соціальна і здоров'язбережувальною; громадянською та історичною; мистецькою; з фізичної культури). Змістове наповнення профільного навчання складається 3 профільних предметів - які відповідають обраному профілю/напряму навчання і передбачають поглиблене вивчення предметів обраного профілю; предметів за вибором - загальноосвітні чи профільнобазовані, які надають можливість удосконалювати знання учням 3 обраної галузі шляхом вивчення поглиблених модулів з фаху; міжпредметні курси орієнтовані на формування ключових компетентностей (уміння вчитися, використовувати інформаційні технології, критично мислити, приймати рішення та розв'язувати проблеми; здобувати нові знання протягом життя; працювати в команді). Загалом, під профільним навчанням розуміють процес диференціації й індивідуалізації, що дає змогу за рахунок змін у структурі, змісті й організації освітнього процесу повніше враховувати інтереси, нахили і здібності учнів, їх можливості, створювати умови для навчання старшокласників відповідно до їхніх освітніх і професійних інтересів і намірів щодо соціального i професійного самовизначення. Таким чином забезпечуються умови для якісної освіти старшокласників у відповідності до індивідуальних нахилів, можливостей, здібностей, потреб.

Важливо також зазначити, що загальноосвітню підготовку та профільне навчання учнів, що входять у змістовий компонент технології формування індивідуальної освітньої траєкторії, необхідно організовувати на засадах розвивально-продуктивного інтегративного підходу, який забезпечує інтегроване навчання шляхом побудови модульної програми і сприятиме формуванню в молоді здатності неординарно, творчо та критично мислити. Для досягнення успішних результатів необхідно ієрархічно вибудовувати систему цілей й результатів, зокрема, за таксономією Б. Блума [4], де перші три категорії - знання, розуміння, застосування - $є$ результатом найпростішого рівня навчальних цілей і потребують від учнів мисленнєвих операцій низького рівня, а наступні три - аналіз, синтез, оцінювання - вимагають застосування мислення високого рівня.

Особливістю змістового компоненту технології формування індивідуальної освітньої траєкторії учнів профільної школи $\epsilon$ активна професійна орієнтація, проведення профінформаційних заходів та впровадження новітніх форм профінформаційної роботи 3 учнівською молоддю, що сприятиме формуванню активної профорієнтаційної позиції, яка відповідає суб'єктивним і об'єктивним умовам вільного та свідомого професійного самовизначення особистості. Змістовий компонент включає ознайомлення зі змістовою й структурною характеристикою професії, діагностування індивідуально-психологічних особливостей, здібностей, професійно-важливих якостей особистості та прогнозування на цій основі успішності оволодіння професією, оцінювання професійної придатності старшокласників.

Варіативний курс з професійної кар'єри орієнтований на опанування 
сукупності знань, необхідних для успішного розвитку професійної кар'єри, зокрема, це соціальні, психологічні, управлінські та кар'єроорієнтовані знання. Так, соціальні - це знання загальних соціологічних теорій, соціальних процесів; знання соціальних спільнот та способів соціальної реалізації у професії; знання із соціальної відповідальності та комунікацій у соціумі. Психологічні знання визначаються сукупністю психологічних знань з образу професії, уявленнями про професійну діяльність, конкретизацією кар'єрного сценарію, узгодженням життєвих і професійних цілей, знання з предметної області та розуміння професійної діяльності. Управлінські знання - це система знань 3 менеджменту та самоменеджменту, підвищення самоефективності.. Кар'єроорієнтовані знання - це знання з професійної кар'єри, з ії планування і розвитку в професійної діяльності. У варіативному курсі з професійної кар'єри розкривається поняття успішної кар'єри, висвітлюється поетапність ії реалізації, до навчального матеріалу входить інформація щодо планування, розвитку, управління кар'єрою. Також вивчаються основи самоменеджменту, що дасть змогу учнівській молоді максимально використовувати власні можливості свідомого керування перебігом свого життя й подолання кризових обставин в особистому, а в майбутньому і в професійному житті [5].

Прочесуально-координуючий компонент технології формування індивідуальної освітньої траєкторії учнів профільної школи забезпечує організацію освітнього процесу відповідно до поставлених цілей, активне використання методів і сучасних форм навчальної діяльності учнів та вчителів, 3 обов'язковою координацією навчання, що спрямовано на досягнення поставлених цілей. Цей компонент забезпечує динамічність, привабливість навчальної діяльності для учнів за рахунок різноманітності організаційних форм взаємодії учасників освітнього процесу; створення атмосфери інтелектуального пошуку, навчального діалогу, креативності та педагогічної підтримки. важливо, що відбувається актуалізація раніше вивченого теоретичного матеріалу і його інтерпретація 3 нових позицій - 3 позицій вирішення проблем. для цього використовується імітаційне моделювання; аналіз конкретних проблемних ситуацій; розігрування ситуацій в ролях; спецкурси і спецсемінари; ігрове проектування. Формами підготовки до розвитку професійної кар'єри позиціоновано такі: лекція-бесіда, лекціядискусія, проблемна лекція, робота у групах, дискусія, круглий стіл, ситуаційні вправи за методикою Life-Work-Planning, тренінг, майстер-клас, воркшоп, консультація, блог, портфоліо, фріланс-проєкт. Застосування активних форм і методів навчання сприятиме емоційному тонусу, тренуванню інтуїції та фантазії, імпровізаційних здібностей старшокласників.

У процесі формування індивідуальної освітньої траєкторії учнів профільної школи необхідно застосовувати стимули щодо ефекту результативності - орієнтація на творче застосування одержаних знань, осмислення нової інформації з позиції тактичних i стратегічних задач навчання; формування власної позиції, виконання спеціальних творчо- 
пошукових завдань, участь у волонтерстві.

Процесуально-координуючий компонент технології формування індивідуальної освітньої траєкторії учнів профільної школи передбачає інформатизацію освітнього процесу, що охоплює медіалізацію (формування медіаграмотності), комп'ютеризацію, інтелектуалізацію (розвиток здібностей, сприйняття і продукування інформаціі).

Контрольно-регулюючий компонент технології формування індивідуальної освітньої траєкторії учнів профільної школи спрямований на дієвість функціонування всієї моделі освітнього процесу, внесення корективів щодо оптимальності організаційної структури, контролю результатів навчання, що здійснюється за допомогою розробки засобів діагностування на компетентнісній основі. Насамперед, це підготовка тестових методик різноцільового призначення: тест досягнень; критеріально орієнтовані тести; ситуаційний тест тощо. Цей компонент технології також орієнтований на оцінювання здатності до саморефлексії й адекватної самооцінки результатів. Контроль формування індивідуальної освітньої траєкторії учнів профільної школи забезпечує зворотний зв'язок в освітньому процесі i визначає необхідність внесення в цей процес відповідних змін, що сприятиме його вдосконаленню.

Висновки. Технологія формування індивідуальної освітньої траєкторії учнів профільної школи це забезпечення умов для якісної освіти старшокласників у відповідності 3 їхніми індивідуальними нахилами, можливостями, здібностями і потребами, успішна професійної орієнтації учнів на майбутню професійну діяльність. Така технологія розкриває можливості активної позиції старшокласників у засвоєнні знань, розвитку індивідуальноособистісного потенціалу, активної профорієнтаційної позиції, зростанні їхнього інтересу до професійної кар’єри.

\section{Лimepamypa:}

1. Закону України «Про освіту»(2017) https://zakon.rada.gov.ua/laws/show/2145-19\#Text

2. Дубасенюк О.А. Теоретико-технологічні засади впровадження особистісно орієнтованого підходу у професійнопедагогічній підготовці майбутнього вчителя. Професійна педагогічна освіта: особистісно орієнтований підхід : монографія. Житомир : Вид-во ЖДУ ім. І. Франка, 2012. С. 14-40.

3. Державний стандарт базової середньої освіти (2020) https://osvita.ua/legislation/ Ser_osv/76886/

4. Anderson L. W., \& Krathwohl, D. R. (2001). A Taxonomy for Learning, Teaching and Assessing: A Revision of Bloom's Taxonomy of Educational Objectives: Complete Edition. New York: Longman.

5. Алєксєєва, С. Підготовка майбутніх дизайнерів до розвитку професійної кар'єри: теорія і практика. Монографія. Київ: Міленіум, 2018. 484 c. https://http://lib.iitta.gov.ua/id/eprint/727617

\section{References:}

1. Zakonu Ukrainy «Pro osvitu»(2017). [The Law of Ukraine "On Education"] (2017) (n.d.). zakon.rada.gov.ua. Retrieved from. https://zakon.rada.gov.ua/laws/show/2145-19\#Text [in Ukrainian]. 
2. Dubaseniuk O.A.(2012) Teoretyko-tekhnolohichni zasady vprovadzhennia osobystisno oriientovanoho pidkhodu u profesiinopedahohichnii pidhotovtsi maibutnoho vchytelia. [Theoretical and technological principles of implementing a personality-oriented approach in the professional and pedagogical training of future teachers]. Zhytomyr: Publishing house of ZhSU named after I. Franko. [in Ukrainian].

3. Derzhavnyi standart bazovoi serednoi osvity (2020). [State standard of basic secondary education (2020)]. Retrieved from. https://osvita.ua/legislation/Ser_osv/76886/ [in Ukrainian].

4. Anderson L. W., \& Krathwohl, D. R. (2001). A Taxonomy for Learning, Teaching and Assessing: A Revision of Blooms Taxonomy of Educational Objectives: Complete Edition. New York: Longman. [in USA].

5. Alieksieieva, S.(2018) Pidhotovka maibutnikh dyzaineriv do rozvytku profesiinoi kariery: teoriia i praktyka. [Preparing future designers for professional career development: theory and practice], Kyiv: Millennium Retrieved from. https://http://lib.iitta.gov.ua/id/eprint/727617 [in Ukrainian]. 